to untreated samples, as evidenced by the growth of this indicator to $85 \%$.

2. Water-repellent properties of cotton fabric treated with this composition increase by $15 \%$ compared to the original sample.

3. Coefficients of air permeability of the fabric treated with the proposed composition are reduced by $4 \%$.

\section{REFERENCES}

1. Razuvayev A. V. Final finishing of textile materials with biocidal preparations// News of higher educational institutions. Chemistry and chemical technology, Ivanova, 2010. №8. - P. 3-7. [in Russian].

2. Pehtasheva E. L. Microbiological resistance of materials based on natural macromolecular: dissertation of Doctor of Technical Sciences: 05.19.08. -Moscow, 2004. - 312 p. [in Russian].

3. Krichyevskyi G. E. Chemical Technology of Textile Materials: A Textbook for Universities in Three Volumes, Moscow, 2001. №3.- 298 p. [in Russian].
4. Textile Fibers and Materials, 2006 [Electronic resource] - Access mode. URL: http://biocides.ru/page637298 (date of application 12.05.2006). [in Russian].

5. Ding, P. \& Ding, Y. Stories of Salicylic Acid: A Plant Defence Hormone// Trends in Plant Science. - 2020. №4 - P. 1921-1938. [in Russian].

6. Pubchem National Library of Medicine, National Center of Biotechnology Information [Electronic resource] - Access mode. URL: https://pubchem.ncbi.nlm.nih.gov/compound/Salicylic -acid (date of application: 16.09.2004). [in Russian].

7. Liquid Glass Technology, Protecting the things you care about with eco-friendly liquid glass technology, 2017 [Electronic resource] - Access mode. URL: https://www.liquidglassnanotech.com/ 2017/08/07/what-is-liquid-glass/ (date of application: 17.10.2017). [in Russian].

8. ST RK ISO 20743-2012 Textile. Determination of antibacterial activity of products with antibacterial treatment. State Standard of NurSultan: Publishing House of Standards, 2012. - 56 p. [in Russian].

\title{
DEVELOPMENT OF A POLYMER COMPOSITION TO PROTECT TEXTILE MATERIAL FROM BIO-DAMAGE
}

\author{
A. BURKITBAY $Y^{l}$, V.M. SATAYEVA ${ }^{l}$ \\ ( ${ }^{1}$ Almaty Technological University» JSC, Almaty, Kazakhstan) \\ E-mail: venera.zhangazina@mail.ru
}

The article presents a method for increasing the microbiological resistance of textile materials under operating conditions. Studies were conducted using polyvinyl alcohol (PVA), maleic acid (MA) and a solution of silver ions (SI). This fabric was treated with an dressing composition to improve the antimicrobial properties of the textile material. In addition, research has been conducted to identify the physical and mechanical properties of samples treated with different concentrations of dressing composition, to prevent negative effects on the protection function and practicality of wear. The study revealed the most optimal concentrations of the composition components: PVA - $8 \mathrm{~g} / \mathrm{l}, \mathrm{SI}-50 \mathrm{ml} / \mathrm{l}, \mathrm{MA}-5 \mathrm{~g} / \mathrm{l}$.

Keywords: composition, fabric Premier Standard 210, microbiological tests, antimicrobial properties, fungi.

\section{ТОҚЫМА МАТЕРИАЛЫН БИО ЗАҚЫМДАЛУДАН ҚОРҒАУ ҮШІН ПОЛИМЕРЛІ КОМПОЗИЦИЯНЫ ӘЗІРЛЕУ}

\author{
А. БУРКИТБАЙ, В.М. САТАЕВА
}

('«Алматы технологиялық университеті» АҚ, Алматы, Қазақстан)

E-mail: venera.zhangazina@mail.ru

Мақалада пайдалану жавдайында тоқыма материалдарының микробиологиялық беріктіzін арттыру әдісі ұсынылган. Поливинил спиртін (ПВС), малеин қышқылын (МК) жәәе кү- 
міс иондарының (КИ) ерітіндісін пайдалана отырып зерттеулер жүүгізілді. Бұл мата тоқыма материалының микробқа қарсы қасиеттерін жсақсарту үшін таңдалган реагенттердің негізінде аппретпен өңделген. Бұдан басқа, аппреттің әртүрлі концентрацияларымен өңделген үлгілердің физика-механикалық қасиеттерін анықтау үшін, қоргау функцияларына және кию тиімділіхіне теріс әсерін болдырмау үшін зерттеулер жүргізілді. Зерттеу нәтижесінде композиция компоненттерінің барынша оңтайлы шогырлануы анықталды: ПВС -8 г/л, КИ -50 мл/л, МК - 5 г/л.

Негізгі сөздер: композициялық құрамы, Премьер Standard 210 матасы, микробиологиялық сынаулар, микробқа қарсы қасиеттері, зең саңырауқұлақтары.

\title{
РАЗРАБОТКА ПОЛИМЕРНОЙ КОМПОЗИЦИИ ДЛЯ ЗАЩИТЫ ТЕКСТИЛЬНОГО МАТЕРИАЛА ОТ БИОПОВРЕЖДЕНИЙ
}

\author{
А. БУРКИТБАЙ ${ }^{1}$, B.М. САТАЕВА ${ }^{1}$ \\ ( ${ }^{1} \mathrm{AO}$ «Алматинский технологический университет», Алматы, Казахстан) \\ E-mail: venera.zhangazina@mail.ru
}

В статье представлен способ повыщения микробиологической стойкости текстильных материалов в условиях эксплуатации. Проведены исследования с использованием поливинилового спирта (ПВС), малеиновой кислоты (МК) и раствора ионов серебра (ИС). Данная ткань была обработана аппретом на основе выбранных реагентов для улучшения антимикробных свойств текстильного материала. Кроме того, проведены исследования для выявления физико-механических свойств образцов обработанных разными концентрациями аппрета, для предотврацения отрицательного влияния на функции зациты и практичности носки. В результате исследования выявлены наиболее оптимальные концентрации компонентов композиции: ПВС -8 г/л, ИС -50 мл/л, МК $-52 / л$.

Ключевые слова: композиционный состав, ткань Премьер Standard 210, микробиологические испытания, антимикробные свойства, грибы.

\section{Introduction}

Typical requirements for standard employee's work wear are usually reduced to ensuring its protective functions and practicality of wear. In recent years, the question has arisen of the need to create completely new materials necessary for special clothing. Certain substances and finishing methods are used to give certain properties.

Due to the huge material losses caused by the action of microorganisms, at the moment, more attention is paid to the biosecurity of various materials, including textiles, which are damaged during their production, storage and operation [1].

Materials and research methods

Laboratory studies were conducted using physical, mechanical, and microbiological testing methods.

The main objects of research in this work were:

- fabric Premier Standard 210 (article 81423);

- chemical compounds: polyvinyl alcohol, maleic acid, silver ion solution.
Results and their discussion

We have conducted research on the development of a composition for sizing mixed fabrics in order to improve the antimicrobial properties of textile materials under operating conditions. Maleic acid (MA), polyvinyl alcohol (PVA) and a solution of silver ions (SI) were taken in the composition of the sizing composition.

A fabric sample of $20 \times 20 \mathrm{~cm}$ it was treated with an aqueous solution of polymer compositions of various concentrations [2]. Concentrations are shown in table 1.

Microbiological studies were performed on untreated and treated samples of mixed fabric [3]. Aspergillus niger, Penicillium brevi and Trichoderma viride fungi were used as test cultures to test for fungal resistance.

The tissue samples under study were infected with a fungi suspension and transferred to Petri dishes. Next, Petri dishes were placed in a desiccator with water. The desiccator with water was used to provide the necessary 
humidity. Incubation was carried out for 28 days at a temperature of $30^{\circ} \mathrm{C}$ [4]

As a result, after 28 days, the growth of Penicillium brevi and Trichoderma viride fungi was detected on the untreated tissue sample. The intensity of fungal germination was 5 points (noticeably extensive tissue damage by fungi). The growth rate of the Aspergillus niger fungus in the control sample was estimated at 3 points (noticeable growth, but not over the entire surface of infection).

The growth of Penicillium brevi and Aspergillus niger fungi was observed on the fabric samples treated with this composition, but the intensity of their germination was insignificant, and the growth of Trichoderma viride was suppressed (Fig.1).

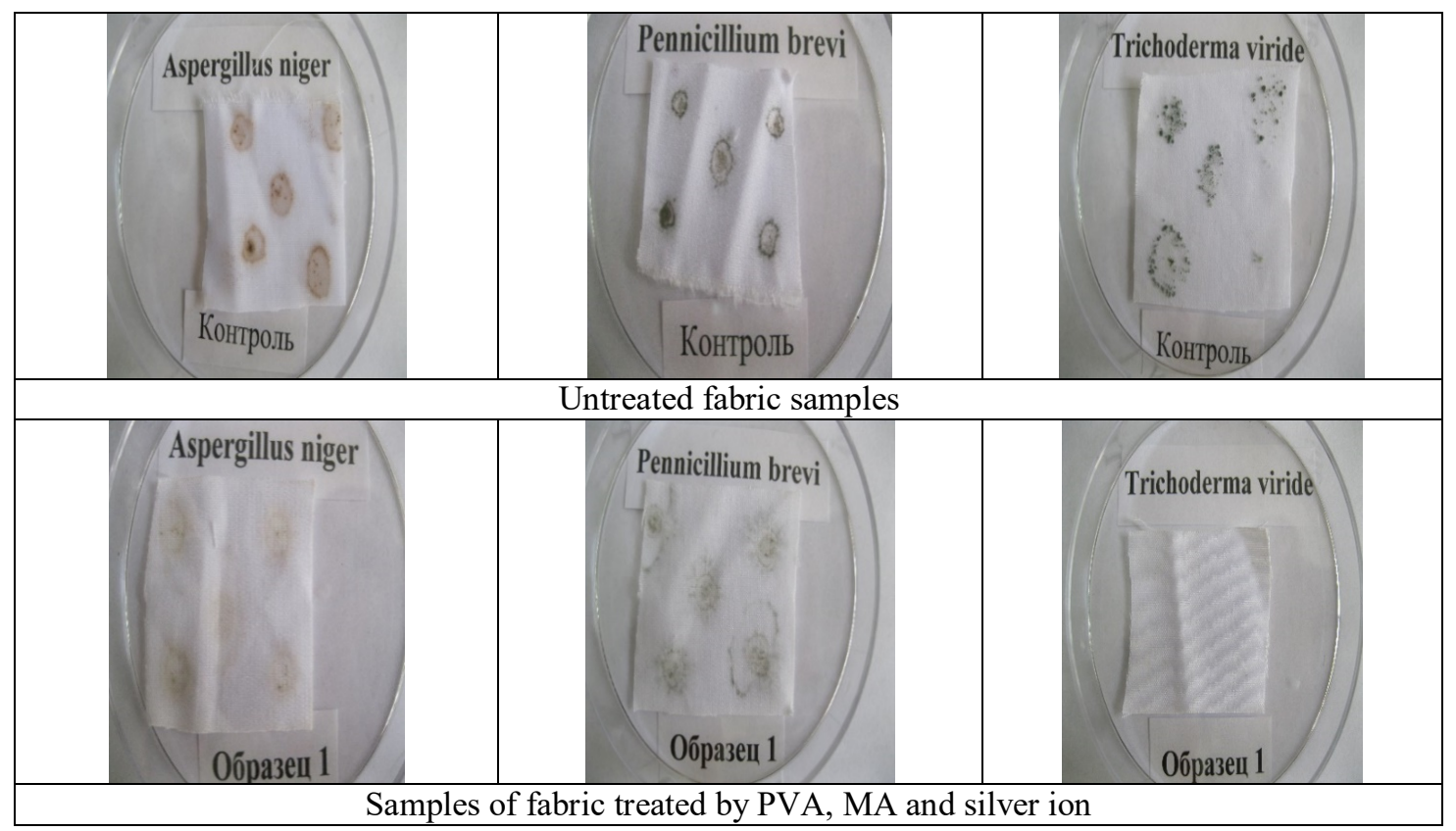

Figure 1 - Fabric samples exposed to fungi

The contamination of fabric samples was also investigated. For verification, swabs were taken from fabric samples. Swabs were taken using sterile moistened cotton swabs. Before seeding the washings, $5 \mathrm{ml}$ of an isotonic sodium chloride solution was added to the swab. The tampon was washed thoroughly, after which 0.1 $\mathrm{ml}$ of flushing fluid was placed in a Petri dish with nutrient medium. The cups were placed in a thermostat at $30^{\circ} \mathrm{C}$. A preliminary count of the grown colonies was made after 48 hours, the final - after 72 hours [5].

As a result of research, it was found that the growth of bacteria in cups containing flushes from untreated tissue samples significantly increased. On the surface of untreated mixed fabric $\left(25 \mathrm{~cm}^{2}\right)$ contains about 200 cells. In the treated fabric samples, microbial growth was absent (Fig. 2).

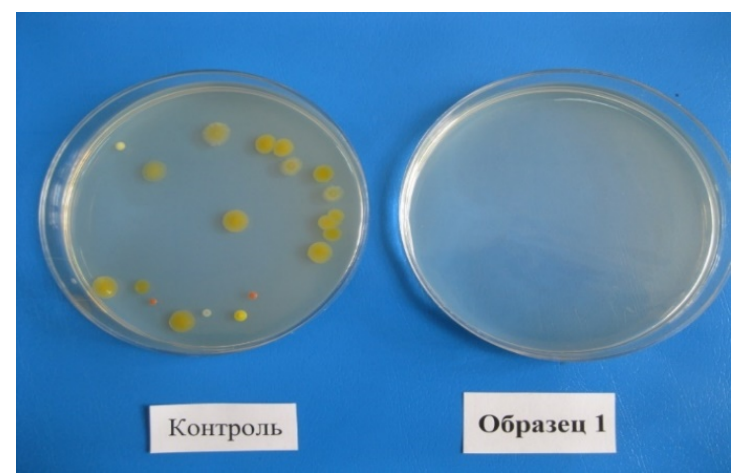

Figure 2 - Bacterial growth from flushing from untreated and treated mixed fabric samples 
Quality assessment of finished fabrics was carried out on the physico-mechanical properties such as crease-resistance, tensile characteristics and abrasion resistance as well as organoleptically.
As a result of the assessment on organoleptic indicators, it was found that the fabric becomes smooth and easily slips off the hands.

Table 1 - Physic and mechanical properties of Premier Standard 210 fabric

\begin{tabular}{|c|c|c|c|c|c|c|}
\hline \multirow[b]{2}{*}{ № } & \multicolumn{3}{|c|}{ Component concentration } & \multirow{2}{*}{$\begin{array}{c}\text { Total angle of } \\
\text { opening of folds, } \\
\left({ }^{\circ}\right)\end{array}$} & \multirow{2}{*}{$\begin{array}{l}\text { Breaking load } \\
\text { (based on), N }\end{array}$} & \multirow{2}{*}{$\begin{array}{l}\text { Air permeability, } \\
\qquad \mathrm{dm}^{3} / \mathrm{m}^{2} \times \mathrm{s}\end{array}$} \\
\hline & $\begin{array}{c}\text { PVA, } \\
\text { g/l }\end{array}$ & $\begin{array}{l}\mathrm{SI}, \\
\mathrm{ml} / \mathrm{l}\end{array}$ & $\begin{array}{c}\mathrm{MA}, \\
\mathrm{g} / 1\end{array}$ & & & \\
\hline 1 & 8 & 100 & 5 & 160 & 372 & 35,5 \\
\hline 2 & 4 & 100 & 5 & 165 & 377 & 33,6 \\
\hline 3 & 8 & 50 & 1 & 178 & 394 & 34,3 \\
\hline 4 & 4 & 50 & 5 & 168 & 405 & 33,5 \\
\hline 5 & 8 & 100 & 1 & 158 & 390 & 35,4 \\
\hline 6 & 4 & 100 & 1 & 159 & 421 & 35,1 \\
\hline 7 & 8 & 50 & 5 & 171 & 499 & 35,8 \\
\hline 8 & 4 & 50 & 1 & 180 & 367 & 35,9 \\
\hline Average index & - & - & - & 167 & 403 & 34,8 \\
\hline $\begin{array}{l}\text { The untreated } \\
\text { fabric }\end{array}$ & - & - & - & 114 & 330 & 33,5 \\
\hline
\end{tabular}

\section{Summary}

The study revealed the most optimal concentrations of the composition components: PVA $-8 \mathrm{~g} / \mathrm{l}, \mathrm{SI}-50 \mathrm{ml} / \mathrm{l}, \mathrm{MA}-5 \mathrm{~g} / \mathrm{l}$

The results of the study revealed the acquired antimicrobial properties of tissue treated with an dressing composition based on polyvinyl alcohol, maleic acid and a solution of silver ions. The acquired properties have shown their resistance to the development of mold fungi on their surface, as well as to the resistance to harmful effects of microorganisms in operating conditions.

\section{REFERENCES}

1. Razuvaev A.V. Final finishing of textile materials with biocidal preparations. News of higher educational institutions. Chemistry and chemical technology. Ivanovo, 2010, vol. 53, issue 8.-P. 3-7. [in Russian]
2. Encyclopedia of polymers. Editorial Board: chief editor V.A. Kabanov and others. - M.: "Soviet encyclopedia", 1974. - Vol. 2. - 1032 p. [in Russian]

3. State standard 9.048-89 Methods of laboratory tests for resistance exposure to mold fungi [Text]. - Introd. 1991-07-01. - M.: State standard of the USSR union: Standards Publishing House, 1989. 23 p. [in Russian].

4. Kutzhanova A.Zh., Tausarova B.R., Burkitbay A. Giving antimicrobial properties to cellulose textile materials. / Materials of the International scientific and technical conference "Food and light industry in the strategy of entering the Republic of Kazakhstan among the 50 most competitive countries in the world". - Almaty, ATU, 2007. - P. 216-218. [in Russian]

5. Prozorkina H.V., Rubashkina P.A. Fundamentals of Microbiology, Virology and immunology: textbook, 4th ed. - Rostov-on-don 2006. - 380 p. [in Russian] 